\title{
From Islamic Input in Medical Program to Islamic Medical Practice: The Journey from Kulliyyah of Medicine to IIUM Medical Centre
}

Nazri MYa, Muhammad Irwan $A^{b}$

${ }^{a}$ Dept. of Orthopaedic, Traumatology and Rehabilitation, Kulliyyah of Medicine, International Islamic University of Malaysia

b Centre for Islamic Economics, Kulliyyah of Economics and Management Sciences, International Islamic University Malaysia

\section{Islamic Medical Program}

Integration and Islamisation program of the medical curriculum was started in 1997 with the Islamic input in Medical Program (IIMP) for undergraduate student as part of the International Islamic University of Malaysia (IIUM) mission to restore the progressive role of the Muslim Ummah. The program consisted of weekly lectures given by lecturers from the Kulliyyah of Medicine and invited lecturers from the Kulliyyah Islamic Revealed Knowledge and Human Sciences, and the Kulliyyah of Laws. ${ }^{1}$ The program was later introduced to the clinical post-graduate program as Application of Fiqh in Medicine in the form of workshop and group discussion to make it more relevant according to the needs of doctors' training to become specialists. ${ }^{2}$ In 2016, IIUM Medical Centre (IIUMMC) which is a 350-bed teaching hospital begins its operation to provide specialist care for the people in Kuantan and surrounding districts. With the development of Malaysian Sharia index, Ibadahfriendly hospital and recently the Sharia Compliant Hospital, there is a need to review this Islamic Medical Program to ensure that the knowledge and experience gained by the students can be applied to clinical after completion of their training.

\section{Islamic Medical Practice}

The government of Malaysia officially launched the Malaysian Sharia Index in February 2015 to bring the governance and delivery of services in alignment with Islamic principles. The index objectively measures

Corresponding author:

Assoc. Prof. Dr Nazri Mohd Yusof

Department of Orthopaedics, Traumatology and

Rehabilitation,

Kulliyyah of Medicine,

International Islamic University Malaysia,

Jalan Hospital, 25150 Kuantan, Pahang.

Tel No : +6095704000

Email : nazriyusof@iium.edu.my the government's performance based on the Maqasid Al-Sharia scale to identify any area for improvement. (JAKIM, 2015). ${ }^{3}$

Towards achieving this goal, the Ministry of Health $(\mathrm{MOH})$ has implemented Ibadah-friendly Hospital (IFH) in many public hospitals since 2014. This is in collaboration with the Islamic Development Department of Malaysia (JAKIM), which has seconded more than 60 religious officers to be placed in $55 \mathrm{MOH}$ 's hospitals nationwide. The IFH policies and guideline were developed in 2017 to consolidate and streamline the program in all public hospitals in this country. ${ }^{4}$

The roles of the IFH unit include organising activities during the Muslim festivals, guiding patients' visitors in the ward, managing rituals for deceased Muslims, performing rituals for new-born, providing educational materials on prayers for sick patients and making sure the prayer rooms are in proper condition. The unit also advises on issues regarding medical fiqh such as the use of non-halal medications and training of the medical staff. ${ }^{5}$

Sharia Compliant Hospital based on MS 1900:2014 by SIRIM (Standard and Industrials Research Institute) was awarded to AnNur Specialist Hospital in 2015. MS 1900:2014 is a sharia-based quality management system standards developed by SIRIM in collaboration with other government bodies and higher education institutions. The Sharia Advisory Council was created in the organisation to ensure that all standard operating procedures (SOP) conformed with the Sharia. ${ }^{6}$

Relationship of ibadah friendly to sharia-compliant hospital

Worshipping Allah alone was the reason why he created human as stated in Al-Quran: "And I did not 
create the jinn and mankind except to worship Me." [Al-Quran, 51:56]. In general, ibadah as a part of worship covers anything that is pleasing to Allah and this includes all types of human behaviour; apparent or hidden. ${ }^{7}$ Human beings must devote their entire life to Allah. However, with the passage of time, the concept of ibadah has been erroneously confined by some legal scholars to ritual worships such as prayers, zakat, fasting and pilgrimage. ${ }^{8}$ There is a need to reinforce the general understanding of ibadah that is beyond mere religious rituals to all medical students.

Therefore, treating patients in the hospital and other activities related to patients' care are also an integral part of ibadah. In patient care, devotion starts from the moment patients enter the hospital compound to the registration counter, consultation with the doctors, prescription of medicine, undergoing medical procedures and treatment in the ward, until they are discharged from the hospital. These processes involve contracts, financial transactions and social interactions. The medical students must know that their future profession as medical doctors is part of ibadah that is pleasing Allah if they perform with devotion to seeking His pleasure. For example, it is a priority for a doctor to attend to a sick patient first than to attend congregational prayer when he is working in the emergency department.

The concept of a sharia-compliant hospital is still in the evolutionary state. It is not only confined to the aspects of quality management and helping patients to perform rituals but it also includes infrastructure, facilities, services, finance, governance, social responsibility, work ethics and working culture of the staff, amongst other things. ${ }^{6,9}$ We should be actively contributing to the development of a comprehensive sharia-compliant hospital program base on the Islamic input in medical curriculum which have started more than two decades ago.

It is also important to get input from other sectors like the Muslim friendly hotels and the Malaysian halal industries so that this process could accelerate. We can also learn from the Islamic banking and finance services that have been accepted throughout the world. This view is also shared by Kasule who recommended well-developed operational principles that govern commercial transactions could be used for hospitals as well. ${ }^{10}$
The teaching of Maqasid al-Sharia in the medical curriculum

In order to make the IIMP program relevant to the need of future doctors in sharia-compliant hospitals, the teaching of maqasid al-sharia should be periodically reviewed and updated. This would expose the students to the higher objectives and goals that the sharia intend to achieve, where the whole framework of sharia is aimed towards achievement of benefits and prevention of harms to the human being in this world and the next. ${ }^{11}$ According to Al-Shatibi these benefits and harms could be divided into three levels of priorities based on human need: daruriyyat (essentials), hajiyyat (necessities), and tahsiniyat (embellishments). (Figure 1) ${ }^{12} \mathrm{Al}$-Ghazali, Al-Amidi and several classical scholars viewed that there are five fundamentals that the sharia wants to preserve: religion, life, progeny, intellect and property. ${ }^{13,14}$

The emphasis on higher objectives of sharia would develop critical thinking culture among the medical students where they would go beyond the literal understanding of religious texts and juristic opinions of scholars when looking for plausible solutions for any medical issue. When dealing with an issue, the medical students would be trained to always look at the bigger picture that includes the rationale for any decisions to be made within the overall objectives of Islam and the consequences of such decisions on individual and social welfare.

\section{Maqasid al-Sharia as an overarching principle in clinical decision making}

Under this approach, students exert effort to identify the underlying reasons and wisdom behind many legal rulings derived by previous and contemporary scholars. These reasons and wisdom are the goals that the sharia intend to achieve, while the legal rulings are simply the instruments to realize those goals. Too much emphasis on the legal aspects of specific medical issues over the inherent objectives intended by the Lawgiver leads to the widespread practice of prioritizing form over substance, where some scholars are more concerned with imitating the rulings in heritage rather than analyzing the rationale and conforming with the underlying reasons for such rulings. To avoid this problem, a holistic approach to the teaching of sharia is needed where the overall framework of Islamic law is taken into account in the decision- 
making process. This is the approach used in the teaching of maqasid al-sharia. Furthermore, this approach would equip the students with the correct way of determining the priorities when handling a case. Al-Shatibi formulated five principles to govern the relationship between the priorities, where the essentials are the foundation for necessities and embellishments, and the latter two must be preserved for the sake of the essentials. Damage in the realm of essentials leads to complete damage in necessities and embellishments, but the opposite is not necessarily true. However, total damage in the realms of necessities or embellishments may lead to partial damage in the essentials. In this regard, the less fundamental priorities serve as a sanctuary for the more fundamental priorities. This parable is similar to the famous hadith of Al-Nu'man ibn Bashir (r.a.) where the Prophet (s.a.w.) advises human to avoid doubtful matters since it serves as a barrier that protects human from falling into the forbidden matters, where else a shepherd who graze around a forbidden sanctuary are liable to step inside it (AlBukhari and Muslim). To protect and enhance the essentials, it is generally necessary to protect and enhance the necessities and embellishments as well. These priorities have been established to reinforce, fulfil and preserve each other. ${ }^{15}$ In this regard, the core activity of a sharia-compliant hospital should be aimed towards the preservation of life. Any activities that may enhance this essential service should be performed since it is strongly recommended.

As an example, both doctor and patient should understand that providing a safe and effective treatment is essential since it preserves life. In the field of gynaecology, this preservation can be enhanced if the patient is attended by a female doctor since the patient may feel more comfortable to receive the treatment. However, one must realize that to have a female doctor to treat the patient is a luxury (tahsiniyat) that should not jeopardize the more essential (daruriyyat) priority of preserving life. In the case of an emergency, a male doctor should be allowed to provide treatment. However, the Kulliyyah of Medicine can contribute towards realising this luxury by encouraging more female students to take gynaecology without denying the same opportunity to male students.

The application of Maqasid al-Sharia in medical curriculum and practise at IIUMMC

The five fundamentals of religion, life, progeny, intellect and property; complement each other. For instance, life must be protected in order to preserve religion and vice versa. Any successful treatment performed should not make human to ascribe the success to their capability without properly acknowledging the will of Allah. In the same line, reliance in Allah (tawakkal) should not make human to simply anticipate that He will cure them without putting in the necessary efforts. IIUM MC could contribute towards the preservation of religion by ensuring the doctors would be able to disseminate the correct concepts of human effort and will of Allah when treating their patients. The doctors could play a great role by harmonizing the preservations of life and religion. With the right advice, they could show to the patients that there is no contradiction between the preservations of life and religion. Patients are given many alternatives in Islam concerning their rituals of worship when they are sick. In this regard, the IIMP would equip the medical students with such necessary knowledge of religion that could enhance the preservation of both life and religion in their future medical practice.

The program should also include doctor-patient relationship beyond the hospital environment, which includes proper social support and the comprehensive healthcare system. For example, a sharia-compliant hospital should never deprive any patient of receiving the essential medical treatment to save a life even if the patient is poor. Instead, the hospital staff should be aware of the social supports that are available to help patients with financial difficulties to receive appropriate medical care.

Collaboration with other kulliyyahs is important to develop a comprehensive program which is in line with the sharia-compliant hospital. It is an opportunity for different kulliyyahs like medicine, nursing, pharmacy, allied health and dentistry to collaborate and work together as what should happen in the real world. IIUMMC also provides the opportunity for the students to practise what they have learned in the classroom and workshop.

From a maqasid point of view, the teaching and learning of medical knowledge are required since it is aimed towards the preservation of life and intellect. The essentials in this matter, among others, should include professional medical teachers who are equipped with the relevant expertise, students of knowledge who fulfil the basic 
requirements to learn medicine, and availability of a basic teaching and learning facility. However, if there is no teaching hospital, the teaching and learning process would be limited to classroom theories and concepts only. The existence of a hospital, such as IIUMMC would enhance the delivery and practice of preservation of life and intellect since both the teachers and students would be able to practise the knowledge learnt in class by performing when treatments are implemented. Furthermore, the existence of a hospital would also attract other medical experts who would join the hospital and share their expertise with the students. Hence, IIUMMC can be regarded as a necessity or an embellishment that would enhance the preservation of life and intellect through the teaching and learning of medicine. Without a hospital, the teaching and learning process can still take place but it would be limited and difficult. For instance, the students may need to travel to other nearby hospitals to practise.

\section{CONCLUSION}

The development of the sharia-compliant hospital in the IIUMMC will complete the Islamisation and integration of the medical education program. The process is made that much easier because IIUM has started a strong foundation of knowledge that is needed for the development of sharia-compliant hospital among its students. Furthermore, IIUM can contribute to integrating and applying Islamic principles other than hospital services as well.

\section{REFERENCES}

1. Osman A. Integrating Islamic Value In Medical Teaching Curriculum: IIUM Experience.

Bangladesh Journal of Medical Science. 2013.;12

(2) . 117-120

2. Nazri Mohd Yusof (2017).Integration and Islamisation program for clinical postgraduate students in International Islamic University of Malaysia (IIUM).Int Med J Malaysia.2018; 17(S1): 91-96

3. Jabatan Kemajuan Islam Malaysia (JAKIM), Indeks Syariah Malaysia Model Tadbir Urus Berteraskan Maqasid Syariah, Putrajaya, Malaysia 20

4. Polisi perlaksanaan program hospital mesra ibadah. Bahagian perkembangan perubatan, Kementerian Kesihatan Malaysia KKM.60017/1/24 Jld 2(49)

5. Garis panduan perlaksanaan program hospital mesra ibadah (perspektif Islam). Bahagian perkembangan perubatan, Kementerian

Kesihatan Malaysia KKM.600-17/1/24 Jld 2(49)

6. Shariff SM, Rahman ARA. Shari'ah Compliant Hospital; From Concept to Reality: A Malaysian Experience. Bangladesh Journal of Medical Science. 2016; 15(1):1-4

7. Ibn Manzaūr, Murammad ibn Mukarram ibn 'Alī Al-Ifrīqī Al-Misarī. LisĀn Al- 'Arab. Beirut: DĈr S口ādir, 2003.

8. Zaidan, 'Abd al-Karim. Al-Jami' fi Al-Fiqh AlIslami Al-Mufassal fi Ahkam Al-Mar'ah wa Al-Bait Al-Muslim. Damascus: Mu'assasah Al-Risalah Nashirun, 2012.

9. Zulkifly AH. IIUM Teaching Hospital: The Way Forward? Int Med J Malaysia.2014; 13(1): 1-2

10. Kasule, Omar Hassan. Islamic Hospitals: Guidelines. Paper presented at the $9^{\text {th }}$ International Seminar \& Workshop of the Islamic Hospital Consortium Malaysia held in Kuala Lumpur on 14 June 2013.

11. Ibn 'Abd Al-Salam, 'Izz Al-Din 'Abd Al-'Aziz. Qawa'id Al-Ahkam fi Islah Al-Anam. Damascus: Dar Al-Qalam, 2000.

12. Al-Shātaibī, Abū Ishaāq Ibrāhīm ibn Mūsā. AlMuwāfaqāt. Riyadh: DĈr Ibn Al-Qaīyim li AlNashr wa Al-Tauzī‘, 2013

13. Al-Ghazālī, Abū Hoāmid Muhrammad ibn Muhrammad. Al-Mustas $\mathrm{fā} \min$ ' $l l m$ Al-Usaūl. Beirut: Dār Ihryā’ Al-Turāth Al-'Arabī, 1997.

14. Al-Āmid̄̄, Saif Al-Dīn 'Al̄̄ ibn Abū 'Al̄̄i ibn

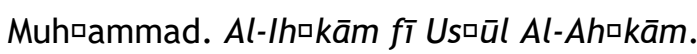
Riyadh: Dār Al-Saamī‘ $\mathbf{i}, 2003$.

15. Al-Raysuni, Ahmad. Nazariyyat Al-Maqasid 'inda Al-Imam Al-Shatibi. Herndon, Virginia: International Institute of Islamic Thought, 2007. 